\title{
Behavioural and biochemical stress responses of Palinurus elephas after exposure to boat noise pollution in tank
}

\author{
Francesco Filiciotto ${ }^{a}$, Mirella Vazzana ${ }^{\mathrm{b}}$, Monica Celi ${ }^{\mathrm{a}, *}$, Vincenzo Maccarrone ${ }^{\mathrm{a}}$, Maria Ceraulo ${ }^{\mathrm{a}, \mathrm{c}}$, \\ Gaspare Buffa ${ }^{a}$, Vincenzo Di Stefano ${ }^{a}$, Salvatore Mazzola ${ }^{a}$, Giuseppa Buscaino ${ }^{a}$ \\ ${ }^{a}$ Istituto per l'Ambiente Marino Costiero U.O. di Capo Granitola, Consiglio Nazionale delle Ricerche, Via del Faro No. 3, 91021 Granitola, TP, Italy \\ ${ }^{\mathrm{b}}$ Dipartimento di Scienze e Tecnologie Biologiche Chimiche e Farmaceutiche, Viale delle Scienze;Edificio 16, Università degli Studi di Palermo, Italy \\ ${ }^{\mathrm{c}}$ Department of Basic Sciences and Foundations, University of Urbino, Campus Scientifico 'Enrico Mattei', Urbino, Italy
}

\section{A R T I C L E I N F O}

Article history:

Available online 6 June 2014

\section{Keywords:}

Underwater noise pollution

Spiny lobster

Marine traffic

Locomotor behaviour

Haemolymphatic stress

Acoustic emission

\begin{abstract}
A B S T R A C T
This study examined the effects of boat noise on the behavioural and biochemical parameters of the Mediterranean spiny lobster (Palinurus elephas).

The experiment was conducted in a tank equipped with a video and audio recording system. 18 experimental trials, assigned to boat noise and control conditions, were performed using lobsters in single and group of 4 specimens. After a $1 \mathrm{~h}$ habituation period, we audio- and video-recorded the lobsters for $1 \mathrm{~h}$. During the experimental phase, the animals assigned to the boat groups were exposed to boat noise pollution (a random sequence of boat noises). Exposure to the noise produced significant variations in locomotor behaviours and haemolymphatic parameters. Our results indicate that the lobsters exposed to boat noises increased significantly their locomotor activities and haemolymphatic bioindicator of stressful conditions such as glucose, total proteins, Hsp70 expression and THC when tested both singly and in groups.
\end{abstract}

(c) 2014 Elsevier Ltd. All rights reserved.

\section{Introduction}

Over the past 50 years, anthropogenic activities, in particular shipping traffic, have produced increasing background sea noise pollution (Ross, 2005; Hildebrand, 2009). Human activity can generate alterations and other significant changes in marine habitats and animals (Myrberg, 1990; McIntyre, 1995; Popper et al., 2004). In recent years, many studies have evaluated the effects of anthropogenic acoustic disturbance on marine organisms (Santulli et al., 1999; Scholik and Yan, 2001; Sarà et al., 2007). These sounds, associated with shipping, seismic surveys, sonar, and many other anthropogenic sources, induce several types of effects in fish and marine mammals (Au et al., 1974; Myrberg, 1990; Thomas et al., 1990; Engås et al., 1996; Scholik and Yan, 2001; Sun et al., 2001; Amoser and Ladich, 2003; NRC, 2003; Romano et al., 2004; Smith et al., 2004; NCR, 2005; Popper et al., 2005; Sandström et al., 2005; Wysocki et al., 2006; Codarin et al.,

Abbreviations: BOAT, Boat noise condition; CTRL, Control condition; BSA, bovine serum albumin; $\mathrm{CHH}$, crustacean hyperglycaemic hormone; DHC, differential haemocyte count; Hsp, heat shock protein; PBS, phosphate buffered saline; PC, protein concentration; SIM, Social Interaction Module; TBS, Tris-buffered saline; THC, total haemocyte count.

* Corresponding author. Tel.: +39 092440600; fax: +39 092440445.

E-mail addresses: monica.celi@unipa.it, monica.celi@cnr.it (M. Celi).
2009; Buscaino et al., 2010; Filiciotto et al., 2013). However, few studies have evaluated the effects of acoustic stimuli on aquatic crustaceans (Christian, 2003; Andriguetto-Filho et al., 2005; Celi et al., 2013; Wale et al., 2013).

In aquatic crustaceans, the impact of environmental stress can directly affect haematological parameters (Perazzolo et al., 2002; Celi et al., 2013). THCs and DHCs have been used to assess crustacean health and the effects of stressful conditions. Decreases in the THC under stressful conditions have been reported for several marine crustacean species (Le Moullac et al., 1998; Sánchez et al., 2001). Moreover, although the response of the DHC to different stressors is not well understood; it has been used as a stress indicator in crustaceans (Jussila et al., 1997; Johansson et al., 2000). Changes in the levels of other plasma components have been described in shrimp under several conditions. Hyperglycaemia and total proteins are typical stress responses to harmful physical and chemical environmental changes, including hypoxia and exposure to air during commercial transport (Le Moullac et al., 1998; Durand et al., 2000; Speed et al., 2001). Hyperglycaemia has been associated with increased circulating crustacean hyperglycaemic hormone (CHH) titres (Stentiford et al., 2001; Lorenzon et al., 2004) and has been used as an index to assess CHH activity and environmental stress. Blood protein levels fluctuate with changes in environmental and physiological conditions and play fundamental 
roles in the physiology of crustaceans, from $\mathrm{O}_{2}$ transport to reproduction to stress responses (Chang, 2005; Lorenzon et al., 2011). These findings suggest that total protein concentration levels (PC) can potentially function as a stress indicator that can be used to monitor the health status of crustaceans (Lorenzon et al., 2011). The bioindicators of stressful conditions in crustaceans include Hsp70 expression (Snyder and Mulder, 2001; Liberge and Barthélémy, 2007). Little is known about the effects of noise on Hsp expression. Wu et al. (2001) showed that Hsp70 expression increased after exposure to a stressful noise in humans, and Hoekstra et al. (1998) reported that the expression of Hsp70 (but not Hsp30, Hsp60 or Hsp90) is increased in birds after exposure to a loud noise.

Behavioural observations, in combination with physiological assessment, may provide a more complete understanding of the homeostatic perturbations of an organism due to external or internal stress stimulus. For example, quantifiable behavioural changes in an organism that are associated with stress and toxicant exposure provide novel information that cannot be gained from traditional toxicological methods, including short-term and sub-lethal exposure effects and the potential for mortality (Bridges, 1997; Henry and Gary, 1986; Saglio and Trijasse, 1998).

A combination of behavioural and physiological approaches may have significant relevance in crustaceans, for which the behavioural patterns in response to stress conditions are not yet well known.

For example, Payne et al., 2007 found that lobsters exposed to very high as well as low sound levels experienced no effect on delayed mortality or damage to the mechanosensory system associated with animal equilibrium and posture. Celi et al. (2013) observed that red swamp crayfish showed altered aggressive behavioural patterns and changes in the components of the haemato-immunological system, such as serum glucose concentration; protein concentration; agglutinating activity; and THC, DHC and Hsp70 expression, when exposed to an acoustic stimulus in a frequency band of $0.1-25 \mathrm{kHz}$, clearly reflecting a stress condition.

The European spiny lobster Palinurus elephas is a common crustacean species along the Mediterranean and northeastern Atlantic coasts (Hunter 1999). This species, which is primarily active at night for feeding and reproduction (Goni and Latrouite, 2005), represents one of the major targets of Mediterranean artisanal fisheries, and while catches are now reduced and sporadic, this fishery has a long history (Goni and Latrouite, 2005; Groeneveld et al., 2006).

In mobile species such as the European spiny lobster, locomotor movement is an important link between the behaviour of individuals and ecological processes (Herrnkind, 1983; Spanier et al., 1988; Lawton and Lavalli, 1995). Density-dependent mechanisms underlying the structure and dynamics of populations and communities are often sensitive to short-term changes in the spatial distribution of individuals due to movement (Milinski and Parker, 1991).

Moreover, spiny lobsters, like other arthropods, produce acoustic signals (Patek, 2002; Patek and Oakley, 2003; Patek and Baio, 2007; Bouwma and Herrnkind 2009; Buscaino et al., 2011a, 2011b). Some authors have assumed that lobsters only produce sounds in an antipredatory context (Patek 2001, 2002; Patek and Oakley, 2003; Bouwma and Herrnkind, 2009), while others suggest that sounds may be used in social context as well (Mercer, 1973).

Although the ability of lobsters to perceive acoustic signals has not yet been documented and even the sensitivity of lobsters to different frequencies remains unknown (Buscaino et al., 2011b), the hypothesis that $P$. elephas is able to perceive boat noise appears reasonable because of the wide bandwidth of acoustic signals generated by boats (from a few $\mathrm{Hz}$ to more than $20 \mathrm{kHz}$; Codarin et al.,
2009; Hildebrand, 2009), as Celi et al. (2013) have already observed in crayfish exposed to a linear sweep with a frequency range of $0.1-25 \mathrm{kHz}$.

In consideration of the concerns described above, the present study investigated the behaviour (locomotor states and acoustic emissions) and biochemical (haemolymphatic parameters) responses of the European spiny lobster (P. elephas) after the exposure to acoustic pollution consisting of boats noises. The locomotor analysis automatically estimated the movement/position events of lobsters, offering a novel, high-throughput method of measuring the relationship of the lobster compared to traditional manual analyses. The biochemical effect on the lobsters was evaluated by estimating the serum glucose concentration; total protein concentration; and THC, DHC and Hsp70 expression as stress indexes.

\section{Materials and methods}

\subsection{Animal housing and experimental design}

The present study was carried out at the Institute for the Marine and Coastal Environment of the National Research Council (CNRIAMC) of Capo Granitola (SW Sicily, Italy). Approximately 80 specimens of European spiny lobster (P. elephas) were captured in May 2013 at a depth of 20-25 m near Mazara del Vallo (SW Sicily, Italy) by fishermen using a commercial trammel net (54-mm inner-panel mesh size, 1200-m length). After capture, the lobsters were transferred to two indoor circular PVC tanks (2.35 m diameter and $1.5 \mathrm{~m}$ depth) for a month-long acclimation period. Before the beginning of the acclimation phase, males were marked using a non-toxic water resistant paint (Markservice, Milan, Italy) that was spread on the central portion of the lobsters' carapace to distinguish them from the females.

The lobsters were fed with frozen molluscs, shrimps and fish ad libitum. After the acclimation period, 36 lobsters (18 males and 18 females) of $301.96 \pm 69.8 \mathrm{~g}$ in weight and $7.73 \pm 0.69 \mathrm{~cm}$ in carapace length (mean $\pm \mathrm{SD}$ ), individually or in groups of 4 individuals, were randomly collected from the holding tanks, were assigned to the trials and were used in only one experiment to meet the assumption of experimental independence. For the experimental procedure, we used only lobsters that had not recently molted. The lobsters were released into the centre of an experimental tank that was identical in size, shape and water composition with the holding tanks. No shelter was present in the experimental tank. The lobsters were deprived of food for 5 days before the start of the experimental trials. All animals were kept under natural photoperiods.

The holding and experimental tanks were equipped with an independent flow-through seawater system from a common source $\left(25 \pm 3.71 \mathrm{~min}^{-1}\right.$; mean $\left.\pm \mathrm{SD}\right)$. Salinity was $36.4 \pm 0.81 \mathrm{ppt}$ (mean \pm SD), and the temperature was $18.61 \pm 0.39{ }^{\circ} \mathrm{C}($ mean \pm SD) during the entire study period.

The experiment was performed during the month of June 2013. During the experimental procedure, the lobsters were exposed to two different acoustic conditions (Fig. 1):

- Boat noise condition (BOAT) - an underwater loudspeaker reproduced the noise from a marine area with high anthropogenic acoustic pollution using a random sequence of boat noises, including recreational boats, hydrofoils, fishing boats and ferry boats;

- Control condition (CTRL) - lobsters were exposed only to the low-level noise of the experimental tank's background noise. The loudspeaker, even if turned off, was not removed from the tank during the control trials to maintain the same landscape as the treatment trials. 


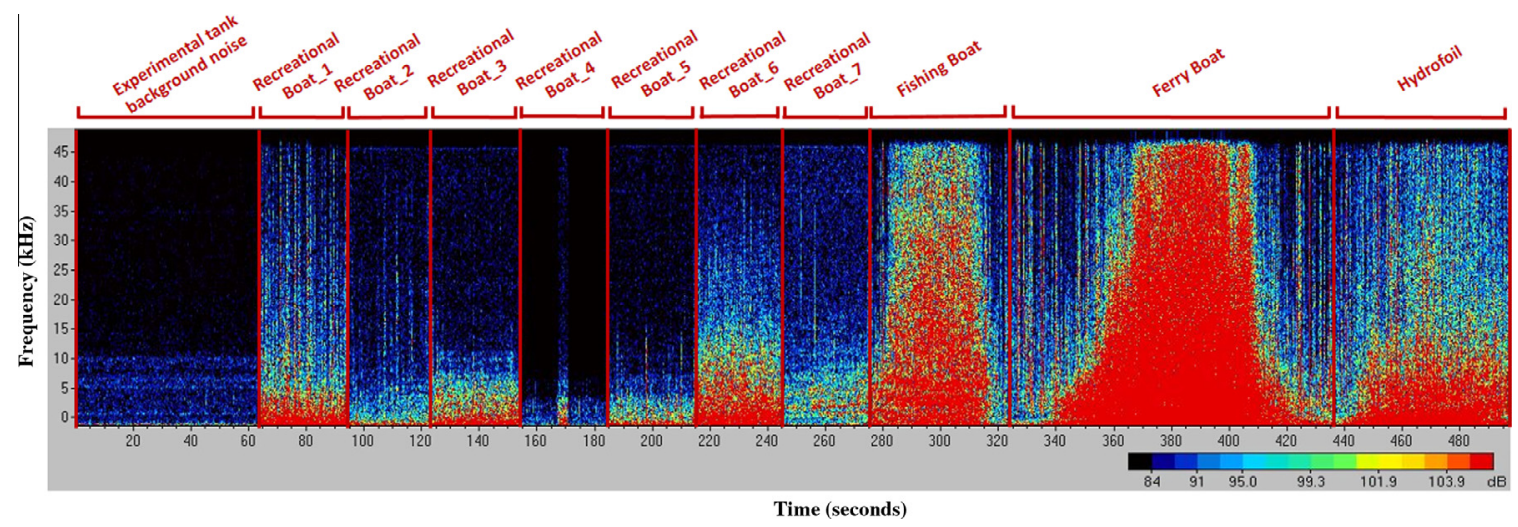

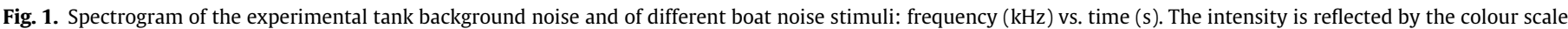

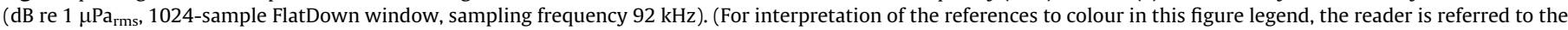
web version of this article.)

In total, 18 experimental trials were performed: six trials with single animal for each condition (the trials had males and females in equal ratio), and three trials with lobsters in groups of 4 animals for each condition (for each group, 2 males and 2 females were used).

After a $1 \mathrm{~h}$ habituation period, we audio- and video-recorded the behaviour of the lobsters for $1 \mathrm{~h}$ ( $30 \mathrm{~min}=$ pre-experimental phase; $30 \mathrm{~min}=$ experimental phase). In the experimental phase, the animals assigned to the "Boat noise condition" were exposed to the BOAT stimulus. Members assigned to the control group were not exposed to any stimuli (only the low-level noise of the experimental tank environment). At the end of the experimental phase, both the control and exposed to boat noise animals were captured with a net and placed on crushed ice for $15 \mathrm{~min}$ to induce torpor or 'cold anaesthesia' to allow sampling of the haemolymph. The samples were collected from the experimental animals, and the lobsters then were transferred into a post-experimental tank and released after recovery.

This experimental procedure was repeated for each specimen in both single and group conditions.

The protocols for animal husbandry and experimentation were reviewed and approved in accordance with EEC Directive $86 / 609$.

\subsection{Acquisition and projection of acoustic stimuli}

To obtain acoustic recordings of the noises from boats and in the experimental tank, we used a calibrated hydrophone (model 8104 , Bruel \& Kjer) with a sensitivity of $-205.6 \mathrm{~dB}$ re $1 \mathrm{~V} / \mu \mathrm{Pa} \pm$ $4.0 \mathrm{~dB}$ in the $0.1-\mathrm{Hz}$ to $80-\mathrm{kHz}$ frequency band. The hydrophone was used with a preamplifier (VP1000, Reson) with a $1-\mathrm{MHz}$ bandwidth single-ended voltage that had a high-pass filter set at $10 \mathrm{~Hz}$ and a 32-dB gain. The equipment was connected to a digital acquisition card (USGH416HB, Avisoft Bioacoustics, set with no gain) managed by the Avisoft Recorder USGH software (Avisoft Bioacoustics). The signals were acquired at 300 kilosamples s $^{-1}$ at 16 bits and were analysed by the Avisoft-SASLab Pro software (Avisoft Bioacoustics). The format of file was .wav.

The marine traffic noise condition was obtained recording in an area near a harbour, characterised by the alternating passages of different types of boats.

The noise in the experimental tank was recorded to characterise the baseline noise of the study environment. During the entire experimental period, the seawater-recirculating flow was directly deployed beyond the tank water surface to prevent any bubbles, and no air pumps were used.
To project the acoustic stimulus of different boats inside the experimental tank, a playlist with the acquired wave file was created. The playlist was projected using the "loop mode" function of the Avisoft-SASLab recorder software (Avisoft Bioacoustics) through the stereo output of the PC connected to a Power Amplifier (type 2713, Bruel \& Kjer - Naerum, Danemark). The amplifier was, in turn, connected to the underwater loudspeaker (Model UW30, Lubell, Columbus, Ohio, USA).

\subsection{Audio and video monitoring system and analysis}

To avoid disturbing the animals inside the experimental tank, a laboratory enclosure was placed $2 \mathrm{~m}$ from the tank, and the equipment required for audio-video monitoring and recording installed there. The acoustic signals emitted by the lobsters, the baseline noise of the tank and the acoustic stimulus were recorded using a calibrated hydrophone (model 8104, Bruel \& Kjer, - Naerum, Danemark) with a sensitivity of $-205.6 \mathrm{~dB}$ re $1 \mathrm{~V} / \mu \mathrm{Pa} \pm 4.0 \mathrm{~dB}$ in the $0.1 \mathrm{~Hz}$ to $80 \mathrm{kHz}$ frequency band. The hydrophone was placed at $0.5 \mathrm{~m}$ depth and close to the tank wall. The equipment was connected to a digital acquisition card (USGH416HB, Avisoft Bioacoustics, septate with $40 \mathrm{~dB}$ gain) managed by dedicated Avisoft Recorder USGH software (Avisoft Bioacoustics). The signals were acquired at 300 kilosamples $\mathrm{s}^{-1}$ at 16 bits and analysed by the Avisoft-SASLab Pro software (Avisoft Bioacoustics).

In Fig. 2, the experimental tank background noise (CTRL) is compared to the mean power spectrum of boats stimulus (BOAT).

To count the acoustic emission by a lobster, a "Pulse Train Analysis" tool from SASLab Pro were used. Because in the experimental tank noise at low frequencies is present, especially for the trial with acoustic stimulus (see Fig. 2), the wave files were filtered (High-Pass $30 \mathrm{kHz}$ ). Acoustic rasps emitted by lobster are, however, visible at frequencies higher than $30 \mathrm{kHz}$ (Buscaino et al., 2011b).

The video system was used to monitor the lobsters' behaviour and was synchronised with the system used to record the acoustic signals.

Videos for behavioural monitoring were recorded with an analogical camera (model 830, Skynet Italia s.r.l.) placed on the top of the experimental tank. The camera was linked to a PC, and the files were managed by Nero Vision 12.0 (Nero Development \& Services GmbH, Germany).

Initially, videos were observed with the aim to detect escape behaviours, such as Tail Flip events. A visual continuous sampling procedure (each observed event was annotated in a sampling table) was applied only for Tail Flip and was performed because 


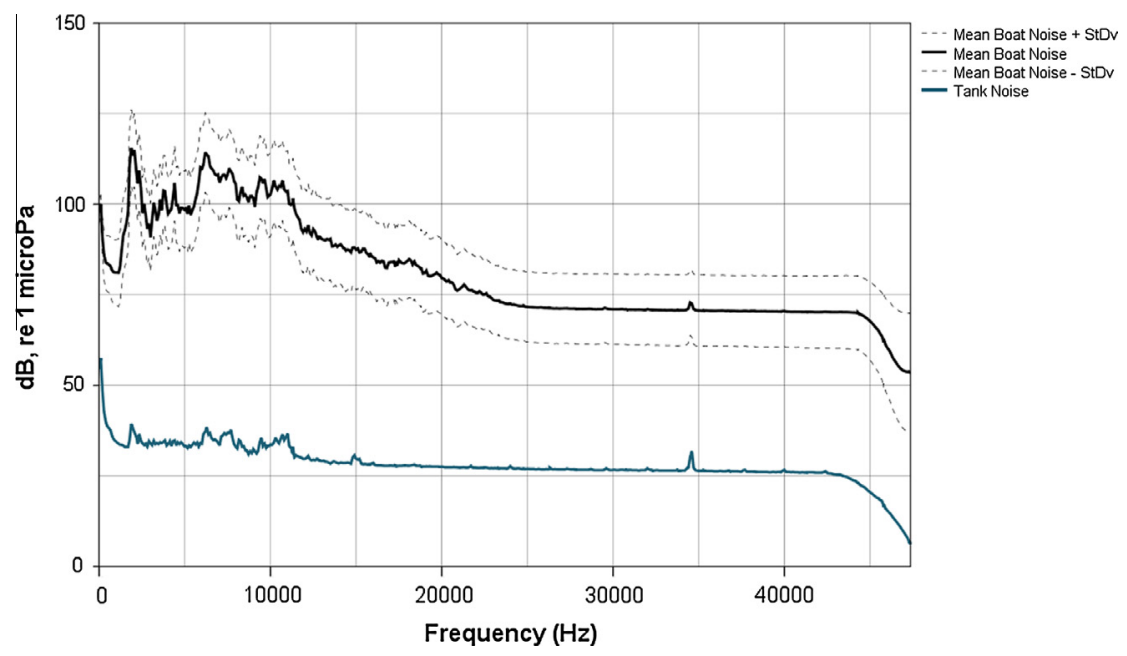

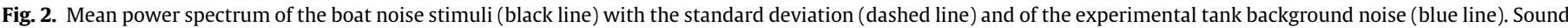

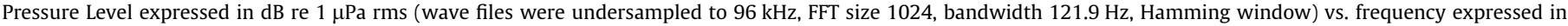
Hertz. (For interpretation of the references to colour in this figure legend, the reader is referred to the web version of this article.)

the automatic software was unable to identify and measure this specific behavioural event, which is characterised by a rapid flexion of the extended abdomen, one or more times, which results in propelling the lobster to a new location (Lavalli and Herrnkind, 2009; Buscaino et al., 2011a).

After this preliminary evaluation phase, the videos were analysed with EthoVision XT 9.0 software (Noldus Information Technology, Wageningen, Netherlands). The experimental arena was calibrated across the bottom wall of the tanks, and the calibration axes were placed to designate the origin $(0,0)$ at the tank centre. The trials with a group of animal were analysed by adopting the SIM (Social Interaction Module) that is an add-on to the EthoVision XT program that enables the detection of multiple unmarked animals in a social context and is capable of assessing lobster shoaling behaviour by simultaneously tracking all of the specimens and recording dynamic changes in social behaviour between the subjects. Because marking lobsters with unique colours makes this methodologically difficult, centre-point detection of unmarked animals (using the same algorithms as the marker-assisted tracking) was chosen as the default setting for the experimental group trials, followed by averaging data for each group. The analysis was performed on each frame to distinguish the object(s) from the background on the basis of their grey scale/brightness values and extracting the coordinates of the geometric centre and surface area for each object per frame. Data were acquired at 25 frames per second. In all of the experiments, the subject loss due to misdetection by video-tracking software was $<2 \%$. Behavioural data were exported to Excel to generate total and per-minute plots for each endpoint.

In the trials with single and grouped animals, the behavioural states reported in Table 1 were evaluated.

\subsection{Animal haemolymph sampling}

Lobster haemolymph was collected into a syringe containing an equal volume of anticoagulant $(0.45 \mathrm{M} \mathrm{NaCl}, 30 \mathrm{mM}$ sodium citrate, $26 \mathrm{mM}$ citric acid, $10 \mathrm{mM}$ EDTA) and immediately placed on ice to avoid clotting. Freshly collected haemocytes were examined by light microscopy to perform THC and DHC measurements.

After the cell counts, the samples were centrifuged at $800 \mathrm{~g}$ for 10 min at $4{ }^{\circ} \mathrm{C}$ to obtain the plasma fraction and haemocyte pellets, which were quickly frozen at $-20^{\circ} \mathrm{C}$ and stored for biochemical analysis.

\subsubsection{Characterisation of Palinurus elephas haemocytes}

The total haemocyte count (THC) was performed to determine the total number of haemocytes per millilitre of lobster haemolymph using a Neubauer haemocytometer chamber. Haemocytes were classified according to $\mathrm{Li}$ and Shields (2007) using the presence or absence of cytoplasmic granules as simple criteria. To perform the differential haemocyte count (DHC; \%), a small drop of haemolymph was smeared on a slide, fixed in $1 \%$ glutaraldehyde in sea water and stained with May-Grünwald-Giemsa, dehydrated with absolute ethanol and xylene and then mounted in Eukitt medium (Fluka). Cells were counted in random areas on each slide, and the relative proportions of various classes were computed (Mahmood and Yousaf, 1985). A total of 200 cells were counted on each slide. DHCs were calculated using the following equation:

$$
\text { DHC }=\frac{\text { number of different haemocyte cell types }}{\text { total haemocyte cells counted }} \times 100
$$

\subsubsection{Glucose level in the haemolymph}

Haemolymph glucose was determined by using a glucose assay kit (Sigma, St. Louis, MO). Before measuring glucose, the haemolymph was mixed with $300 \mu$ l of $95 \%$ ethanol and centrifuged at $12,000 \mathrm{~g}$ for $10 \mathrm{~min}$ at $4^{\circ} \mathrm{C}$. A free sample of $100 \mu \mathrm{l}$ of protein was used following the kit's protocol.

\subsubsection{Total protein analysis of haemolymph}

The total protein concentration (PC) of the spiny lobster haemolymph was estimated using a Quibit ${ }^{\circledR} 2.0$ Fluorometer (Invitrogen). The data were quantified with standards.

\subsubsection{SDS-PAGE and Western Blot}

Haemocytes pellets were crushed on ice for $1 \mathrm{~h}$ in $1 \mathrm{ml}$ and lysed in $500 \mu$ l of RIPA buffer, pH 7.5, supplemented with a cocktail of protease inhibitors using a glass daunce homogeniser. Lysates were centrifuged at $15000 \mathrm{~g}$ for $30 \mathrm{~min}$ at $4{ }^{\circ} \mathrm{C}$. The supernatants were collected and dialysed against $50 \mathrm{mM}$ Tris- $\mathrm{HCl}(\mathrm{pH} 7.5$ ), and the protein content was estimated with the Quibit ${ }^{\circledR} 2.0$ Fluorometer (Invitrogen).

The equivalent of $25 \mu \mathrm{g}$ of serum protein and $25 \mu \mathrm{g}$ of total tissues lysates were separated on 7.5\% SDS-PAGE under reducing conditions (Laemmli, 1970). SDS-polyacrylamide minigels were transferred to nitrocellulose membranes using a semidry transfer apparatus (BioRad) and blocked with $5 \%$ bovine serum albumin 
Table 1

Locomotor behavioural states and acoustic signals emitted by the lobsters in single and group tests.

\begin{tabular}{|c|c|c|c|}
\hline Behaviour & Description & Unit & Application test \\
\hline Distance moved & $\begin{array}{l}\text { The cumulative distance travelled by the center point of the } \\
\text { subject from the previous sample to the current on }\end{array}$ & Centimetres & Single/group \\
\hline Mobility & $\begin{array}{l}\text { Calculates the cumulative duration for which the complete area } \\
\text { detected as animal is changing, even if the center point remains } \\
\text { the same }\end{array}$ & Seconds & Single/group \\
\hline Velocity & $\begin{array}{l}\text { Mean Distance moved by the center point of the subject per unit } \\
\text { time }\end{array}$ & Centimetres/seconds & Single/group \\
\hline Movement & $\begin{array}{l}\text { Moving if the subject running mean velocity exceeds the start } \\
\text { velocity of } 1.80 \mathrm{~cm} / \mathrm{s} \text {, the state then becomes Not Moving if the } \\
\text { subject running average velocity reach the stop velocity set below } \\
\text { of } 1.50 \mathrm{~cm} / \mathrm{s}\end{array}$ & Centimetres/seconds & Single/group \\
\hline Inter-lobster distance & $\begin{array}{l}\text { The mean distance between two subjects measured from the } \\
\text { center point of each lobster }\end{array}$ & Centimetres & Group \\
\hline Proximity/Not proximity & $\begin{array}{l}\text { The total amount of time that a subject spent close (within } 5 \mathrm{~cm} \text { ) } \\
\text { to another subject }\end{array}$ & Seconds & Group \\
\hline Tail flip & $\begin{array}{l}\text { Rapid flexion of the extended abdomen, one or more times, which } \\
\text { results in propelling the lobster to a new location (Buscaino et al., } \\
\text { 2011a; Lavalli and Herrnkind, 2009) }\end{array}$ & Number of events & Single/group \\
\hline Acoustic signals & Number of rasps emitted (Buscaino et al., 2011b) & Number of acoustic events/s & Single/group \\
\hline
\end{tabular}

(BSA) in TBS-T (20 mM Trizma base, pH 7.5, $300 \mathrm{mM} \mathrm{NaCl,0.1 \% (v/v)}$ Tween-20 with $0.02 \%$ sodium azide) for $1 \mathrm{~h}$ at room temperature (r.t.). The membranes were incubated over night at $4{ }^{\circ} \mathrm{C}$ with a mouse monoclonal anti-heat shock protein 70 antibody (Sigma, 1:2500 dilution), washed with TBS-T (three times for 5 min each), and incubated with an alkaline phosphatase-conjugated goat antimouse IgG (1:10,000 for $1 \mathrm{~h}$ at r.t.). After washing with TBS-T (three times for $5 \mathrm{~min}$ each), the membranes were incubated with the 5-bromo-4-chloro-3-indolyl phosphate/nitro blue tetrazolium liquid substrate system (BCIP/NBT). Alpha Imager software was used for densitometric analysis of the immunoblotted bands. 36 lobsters (18 males and 18 females) were examined, and each test was repeated in triplicate.

\subsection{Statistical analysis}

Data were tested for goodness of fit to the normal distribution using the chi-squared test. Because different distributions in behavioural and haemolymphatic data were observed, nonparametric and parametric tests were used to compare different values among the trials.

In the first analysis, the differences between males and females and single and group lobsters in pre-test conditions were evaluated with the aim of characterising the baseline condition for each behavioural state. To detect significant differences between males and females and single and group lobsters assigned to pre-condition tests for behavioural parameters, the Mann-Whitney $U$-test was adopted.

After the pre-test condition evaluation, the differences between the values from the pre- and experimental phase were assessed, both for behavioural and haemolymphatic responses. For behaviour, to avoid a subjectivity effect for tested animals, the statistical analysis was applied to the algebraic differences of during- less pre-condition in control and boat tests. The Mann-Whitney U-test was used to evaluate differences between BOAT and CTRL conditions for the following behavioural variables: acoustic rasps emitted; distance moved; mobility state; velocity and movements of the lobsters individually and in groups; and inter-lobster distance and proximity (only for the specimens in the group).

For the haemolymphatic parameters, the $t$-test was used to detect the significant differences between the values of BOAT and CTRL.

$p$-Values of $<0.05$ were considered statistically significant. All statistical analyses were performed using the STATISTICA 7.0 (StatSoft) software package.

\section{Results}

\subsection{Behavioural responses}

\subsubsection{Pre-test (Baseline) condition}

No differences between males and females in tests with both single and grouped animals for all measured behavioural parameters (except for the acoustic signals) were observed. In particular, specimens tested alone showed significantly higher acoustic rasps in comparison to grouped animals (Mann-Whitney $U$-test; $p<0.05$ ).

\subsubsection{Noise pollution effects}

Significant differences in behavioural parameters were detected both for single and grouped specimens, as reported in Fig. 3. In particular, lobsters tested alone and exposed to BOAT conditions showed significantly higher values of the mobility and moving state with respect to lobsters in the CTRL condition (Mann-Whitney $U$-test; $p<0.05$ ).

Grouped lobsters showed significantly higher velocity, distance moved, mobility and moving values in the BOAT condition in comparison to control animals (Mann-Whitney $U$-test; $p<0.05$ ). The opposite conditions were observed for proximity results.

From the visual analysis, no Tail Flip events were observed from the video recordings in both pre- and experimental phases.

\subsection{Cellular and biochemical parameter evaluation}

\subsubsection{THC and DHC}

Three major haemocyte types were identified in the European spiny lobster: hyalinocytes, semigranulocytes, and granulocytes (Fig. 4). Hyalinocytes (H) contained no or a few small granules that appared dark blue after staining, and were often found as a spindle shapes, ranging in size from 15 to $28 \mu \mathrm{m}$. Semigranulocytes (SG) contained many small and a few larger $(>1 \mu \mathrm{m})$ granules, were morphologically ovoid in shape, and ranged in size from 15 to $27 \mu \mathrm{m}$. Granulocytes $(G)$ contained many large $(>1 \mu \mathrm{m})$ granules were round in shape, and ranged from 12 to $22 \mu \mathrm{m}$. Semigranulocytes and granulocytes showed principally pink eosinophilic granulations after staining (Fig. 4). Acoustic stimuli, considering animals in single and in group, significantly affected both THC and DHC (see Table 2).

The number of circulating haemocytes (total hemocyte count, THC) in the spiny lobster for both single and grouped specimens was approximately $10.8 \times 10^{6}$ cells $\mathrm{ml}^{-1}$. THC decreased by approximately $30 \%$ following the acoustics stimulus relative to the initial count (Table 2). 

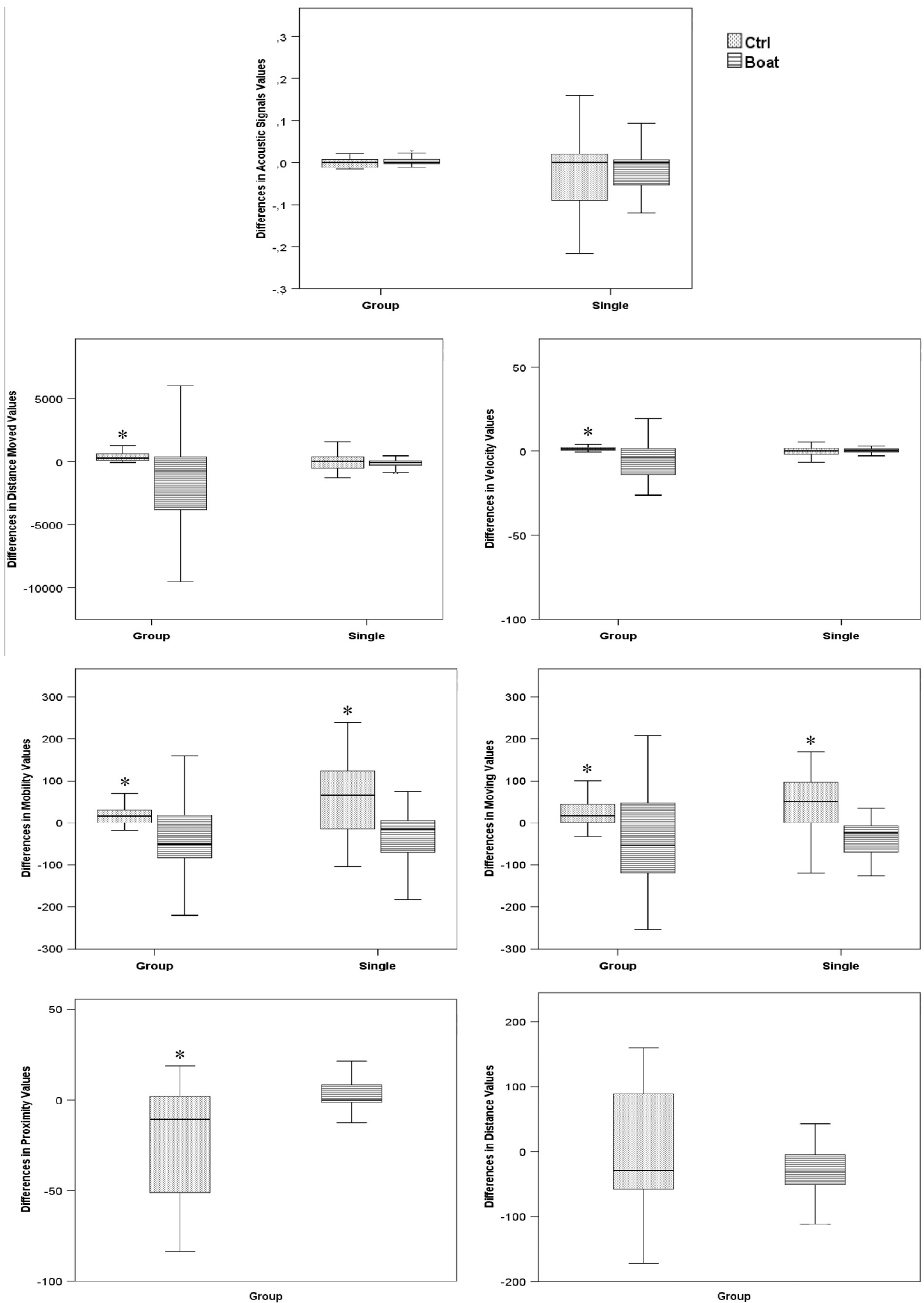

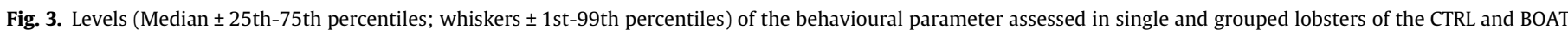
conditions; asterisks represent significant differences $(*=p<0.05)$. 

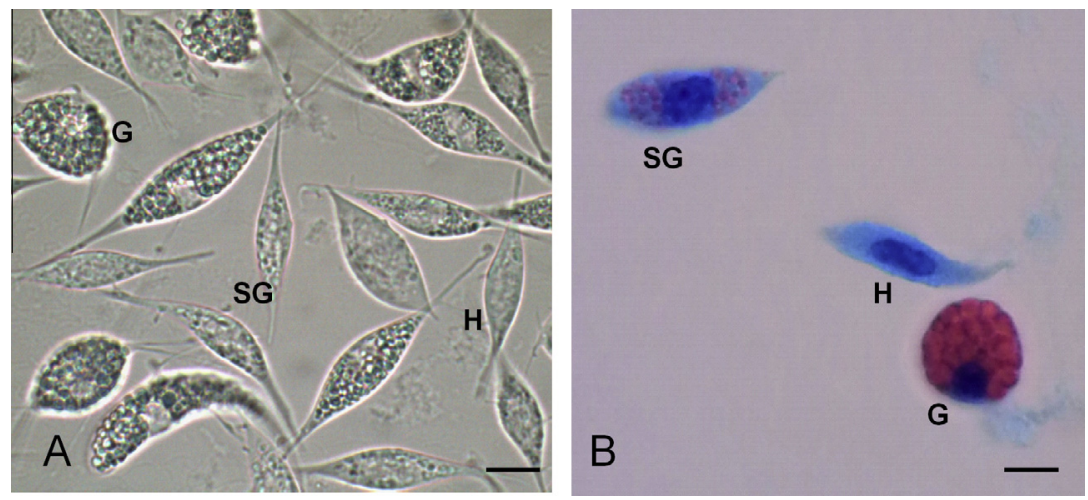

Fig. 4. Light microscopy of haemocytes of the spiny lobster P. elephas (A) no staining and (B) H: hyalinocytes; SG: semigranulocytes; G: granulocytes. Scale bars $=8 \mu$ m.

Table 2

Total haemocyte count (THC) and differential haemocyte count (DHC) in the haemolymph of the control and boat groups. The data represent the means \pm SD $(n=18$ control and $n=18$ test specimens). Significant differences between the control and test groups (BOAT noise condition) are expressed by asterisks.

\begin{tabular}{|c|c|c|c|c|}
\hline & \multicolumn{2}{|l|}{ CTRL } & \multicolumn{2}{|l|}{ BOAT } \\
\hline & Group & Single & Group & Single \\
\hline THC & $10.6 \times 10^{6} \pm 6.5 \times 10^{5}$ & $11 \times 10^{6} \pm 1.6 \times 10^{5}$ & $7.4 \times 10^{6} \pm 7.1 \times 10^{5^{*}}$ & $6.7 \times 10^{6} \pm 9 \times 10^{5}$ \\
\hline Hyalinocytes (\%) & $59 \pm 16$ & $62.5 \pm 12.3$ & $67.7 \pm 7$ & $71.2 \pm 13.5$ \\
\hline Granulocytes (\%) & $34.3 \pm 11.3$ & $33.2 \pm 5.4$ & $27.6 \pm 7.9$ & $24.9 \pm 6.5$ \\
\hline
\end{tabular}

${ }^{*} p<0.01$.

Hyalinocytes represented the cellular type that was more abundant both for single and grouped specimens (control and boat). In particular, after the acoustic stimulus, we observed a slight increased hyalinocytes and a not significant slight decrease of granulocytes and semigranulocytes for both.

No significant differences between single and grouped animals were observed. Moreover, no differences between males and females were observed.

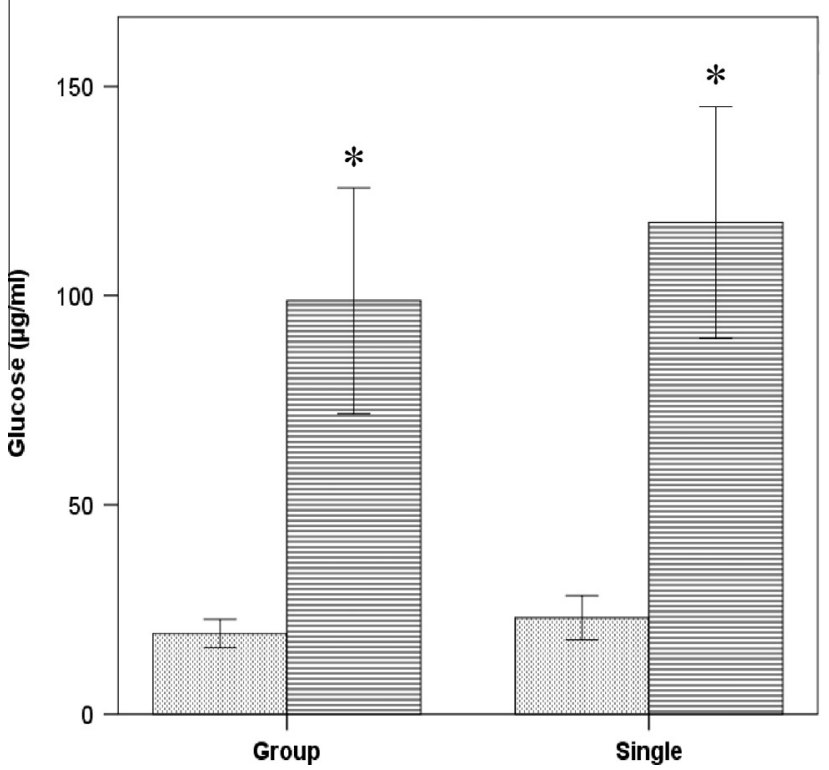

\subsubsection{Serological parameters}

The haemolymph glucose level increased significantly ( $t$-test; $p<0.01$ ), four times, in single and grouped specimens exposed to acoustic stimulus. The total serum protein concentration significantly increased approximately $1.7 \%$ ( $t$-test; $p<0.01$ ) after exposure to acoustic stimulus in both single and grouped lobsters (Fig. 5). No significant differences between males and females were observed.

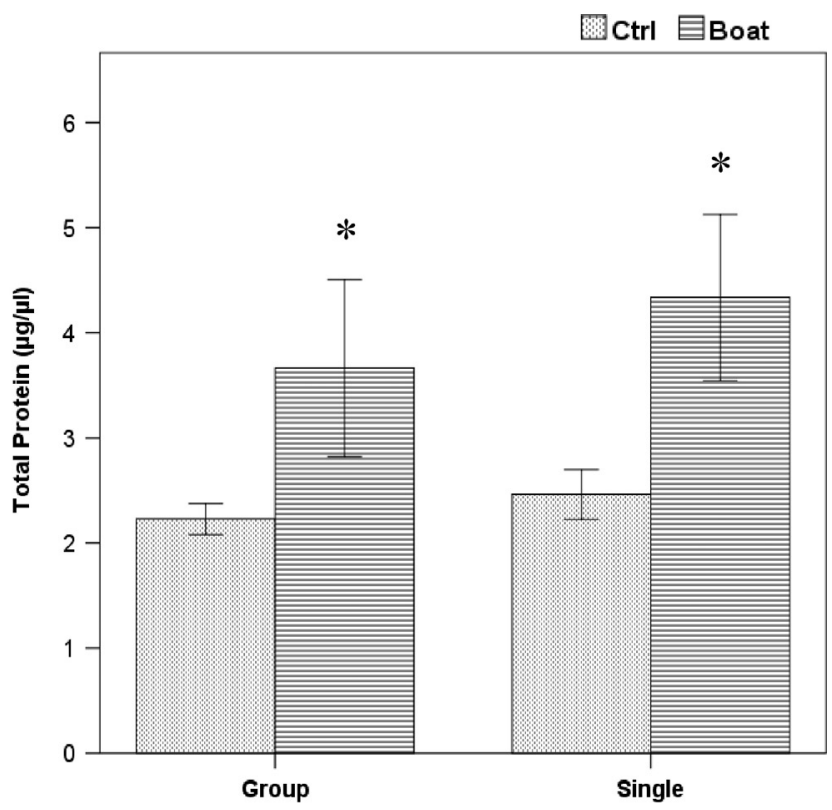

Fig. 5. Means ( \pm Standard Error) of the total protein and glucose levels of lobsters exposed to the BOAT and CTRL conditions; asterisks represent significant differences $(*=p<0.01)$. 
A
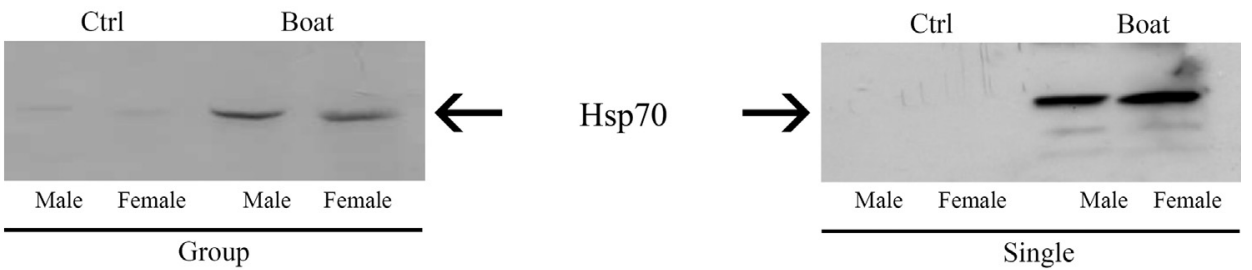

B
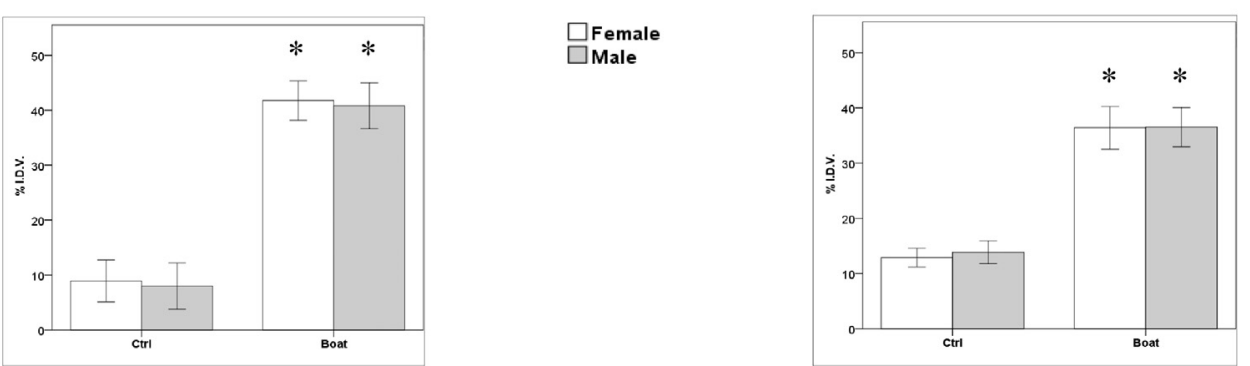

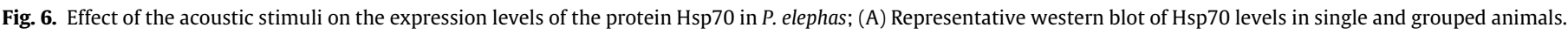

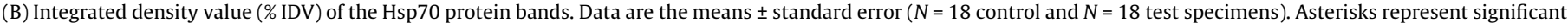
differences between CTRL and BOAT condition $(*=p<0.01)$.

\subsubsection{Hsp70 expression in haemocytes}

To assess the Hsp70 protein production, assays were performed by densitometry analysis of the immunoblotted bands. Fig. $6 \mathrm{~A}$ shows the anti-mouse Hsp70 mAb cross-reacted with a $70 \mathrm{kDa}$ band in circulating haemocytes from both the control and stress groups. A densitometric analysis of Hsp70 protein levels (Fig. 6B) revealed a significant increase in expression in the haemocytes collected from stressed animals ( $t$-test; $p<0.01$ ). Hsp70 expression peaked (threefold higher than the untreated samples) after the period of acoustic stimuli. No differences between single and grouped animals were observed. No differences between males and females were observed.

\section{Discussion}

\subsection{Pre-test (baseline) condition}

The pre-test condition analysis between male and female lobsters indicates that the behavioural parameters measured in the present study are not influenced by sex. This result is in agreement with the findings of Follesa et al. (2009), who did not observe any statistical relationship between the movement patterns and sex of tag-recaptured $P$. elephas inside an area of the central western Mediterranean and its surrounding zone. Golet et al. (2006) obtained the same results from American lobsters (Homarus americanus).

Moreover, the only difference recorded between single and grouped lobsters was the acoustic signals emitted. The higher rasps emitted of single animals with respect to the grouped lobsters are in accordance with the results observed by Buscaino et al. (2011a). Although they explained the numerous instances of sound emissions by the frequent use of anti-predator behaviours (tail flip, lunge, parry, whip and point), actions that are coincident with stridulation, other authors have hypothesised various functional reasons as explanations for rasp production in lobsters, including calling for help from conspecifics, alerting conspecifics to danger, attracting another predator that might interfere with the attacker, aposematism, and a reduction in the kinetic friction between the antenna and the predator to facilitate escape (Bouwma and Herrnkind, 2009; Staaterman et al., 2010). Our results obtained in the basal condition (pre-test) and in the absence of external stimuli suggest that these animals use acoustic signals, probably in addition to chemical signals, to maintain contact with conspecifics and to adopt clustering and aggregation strategies.

\subsection{Behavioural and haemato-immunological responses to noise pollution}

There is a small body of literature on the impact of boats on crustaceans. Wale et al. (2013) report that the boats noise is able to modify the foraging and antipredator behaviour in the shore crabs, increasing the risks of starvation and predation. Although some authors described the disturbance effects of fishing activity on the behaviour, distribution and abundance of spiny lobsters (Davis and Dodrill, 1989; Blonder et al., 1992; Parsons and Eggleston, 2005), no specific data are available regarding the effects of boat noise on this species. This study, for the first time, showed that boat noise pollution influences the behavioural activity and some haemolymphatic parameters of the Mediterranean spiny lobster. Although no data on sensitivity to acoustic signals are currently available for lobsters, our results indicate that $P$. elephas may perceive all or part of the acoustic stimuli projected within the wider bandwidth of their underwater audible rasps characterized by signals with most of energy concentrated in the $2-75 \mathrm{kHz}$ range, with the peak frequency of $19 \mathrm{kHz}$ and peak amplitude of $120 \mathrm{~dB}$ re $1 \mu \mathrm{Pa}$ (Buscaino et al., 2011b).

Lobsters are a mobile species, and their movements are highly related to ecological and biological aspects. In particular, territoriality, nomadism and migration are locomotor behavioural states that have implications for the survival, growth and reproduction of decapod crustaceans (Herrnkind, 1983; Spanier et al., 1988; Lawton and Lavalli, 1995). Our results indicate that the lobsters exposed to boat noises increased their locomotor activities significantly, such as their moving and mobile states when tested both singly and in groups. Grouped animals increased the distance moved and their velocity with respect to CTRL animals. Although no studies have been conducted on the relationship between acoustic stress conditions and the locomotor activity of lobsters, Lavalli and Herrnkind (2009) described that the use of antennae in combination with the rapid contraction of the abdomen musculature (Tail Flip, Rear Back) along with the movement of the walking legs (Pirouette, Walk) gives the spiny lobster useful tools against predator attack during different life-history stages and in several ecological conditions. Moreover, Newland and Chapman 
(1989) observed increased escape behaviours of Nephros norvegicus, such as swimming and tail flipping, in response to the ground gear component of a trawl. In consideration of the previous research and because no tail flip event was recorded in our study, the high values of the locomotor activities of lobsters may indicate a disturbance response, in this case, due to the increasing ambient noise.

These results may be particularly relevant when considering the potential effect of acoustic pollution on some ecological aspects of this species. In fact, the increased swimming activity depletes a large part of the lobster energy budget, as has already been described in fish (Boisclair and Pascal, 1993), and the associated metabolic costs may compromise other biological activities, such as reproductive activities, predator-prey interactions, food acquisition, regulation due to environmental perturbation and migration.

The spiny lobster is a gregarious species (Hunter, 1999; Childress and Herrnkind, 2001) that shares shelters (Childress and Herrnkind, 1997, 2001), aggregates in complex coordinated formations (Herrnkind et al., 2001) and senses olfactory alarm signals (Briones et al., 2008; Shabani et al., 2008). Gregariousness may be evolutionarily favoured because of the benefits gained from associating with conspecifics, such as cooperative predator vigilance, cooperative group defence, cooperative hunting, cooperative offspring care, defence of food patches, or increased reproductive opportunities (Endler, 1991; Lavalli and Herrnkind, 2009). In these cases, the benefits from being gregarious are mutual, even if shared unequally among all members of a group (Vehrencamp, 1983). However, gregariousness may also be a by-product of benefits gained by individuals that use the presence of conspecifics to find and/or evaluate microhabitat conditions (Reed and Dobson, 1993; Stamps, 1994; Stephens and Sutherland, 1999). In the present study, significant lower values of proximity in lobsters subjected to BOAT conditions with respect to those subjected to CTRL conditions were observed, clearly indicating that lobsters exposed to the acoustic pollution tend to abandon the group formation. Buscaino et al. (2011a) observed that when grouped, P. elephas were threatened by different predators, and they left the group that they joined during the control phase and individually sought a new location. Grouped lobsters appeared to abandon the potential anti-predatory benefits and cooperative defence advantages of group formation, preferring to adopt individualistic strategies. The no-cluster formation may be adopted to avoid focusing the attention of predators on a specific place, leading to uncertainty in the choice of target prey, as in many gregarious fish and crustacean species (Brock and Riffenburgh, 1960; O'Brien, 1988; Magurran, 1990), suggesting that this strategy may be adopted by lobsters in response to an imminent threat. The very similar behavioural responses of lobsters recorded in the present experiment indicate that acoustic pollution from boats may represent a danger and stress source for this species. In natural conditions, the individualistic strategy adopted by lobsters (leaving the group and its cooperation advantages) when exposed to a stressor may reduce the foraging efficiency, migration activities and mating chances and increase the risks of predation. For example, during the migration of the Caribbean spiny lobster, queue members spiral into tightly packed rosette (outward-facing pods described in Kanciruk, 1980; Herrnkind et al., 2001) formations to rest in the open; they also form such formations when attacked by predators such as triggerfish (Wainwright and Friel, 2000).

In crustaceans, the haemolymph reflects the physiological status as well as environmental fluctuations through the regulation of its components. Thus, the haemolymph composition of shrimps indicates physiological modifications associated with molting processes, developmental stages, defence mechanisms and environmental stressors.
There are several prior studies on crustaceans that show differences in tissue and haemolymphatic parameters between males and females. However, these differences are generally given in relation to seasonal changes, and each studied species responds differently (Vinagre et al., 2007; Oliveira et al., 2007; Da Silva-Castiglioni et al., 2007).

THCs and DHCs have been used to assess crustacean health and the effects of stressful conditions (Jussila et al., 1997). Decreases in the THC under stressful conditions have been reported for several aquatic crustacean species (Le Moullac et al., 1998; Sánchez et al., 2001; Laurence Mercier et al., 2006). Similarly, under acoustic stimuli, the THCs of our P. elephas specimens were reduced, suggesting the possibility of immune depletion as well as an increased risk of infection. Moreover, acoustic stimuli also altered no significantly the DHC (relative proportions of $\mathrm{H}, \mathrm{SG}$ and SG in the THC). Although the response of the DHC to different stressors is not well understood, it has been used as a stress indicator in crustaceans (Jussila et al., 1997; Johansson et al., 2000). In this paper, we described for the first time the cell types of $P$. elephas, classified into hyalinocytes, semigranulocytes, and granulocytes according to the number and size of granules they contain (Bauchau et al., 1980; Li and Shields, 2007).

Hyperglycemia as a response to various types of stress has been observed in decapod crustaceans exposed to harmful physical and chemical environmental changes (Lorenzon et al., 2004). The regulation of haemolymph glucose is mediated by the release of $\mathrm{CHH}$, which is synthesised in the eyestalk X-organ and stored prior to release from the sinus gland. In this paper, the acoustic stimulus led to a significant increase $(p<0.01)$ in haemolymph glucose levels. These results show that the haemolymph glucose concentration can significantly change in specimens subjected to noise probably due to the high values of locomotor activities of lobster during disturbance response. Thus, under this type of stress, the measurement of glucose haemolymphatic should be considered a good parameter for describing the disturbance of the homeostatic balance of this species.

Blood protein levels fluctuate with changes in environmental and physiological conditions and play fundamental roles in the physiology of crustaceans (Hagerman, 1983; Shafir et al., 1992; Lin and Chen, 2001). The level of total protein in the haemolymph is also dependent on the species, with the highest concentrations observed in penaeids and lower concentrations observed in freshwater crayfish (Palacios et al., 2000; Da Silva-Castiglioni et al., 2007; Buckup et al., 2008). Moreover, the protein level is reflective of an animal's adaptive characteristics and strategies for acclimation (Buckup et al., 2008). Consequently, measuring the protein concentration of a crustacean's blood can provide valuable information to identify its condition (Ozbay and Riley, 2002). Moulting, reproduction, nutritional state, infection, stress response, hypoxia, and salinity variations are some of the factors that affect the relative proportions and total quantities of the haemolymph proteins (Depledge and Bjerregaard, 1989; Oliver and MacDiarmid, 2001; Arcos et al., 2003; Pascual et al., 2006; Ocampo et al., 2003). In this paper, we showed that the levels of protein in the haemolymph were significantly increased in individuals subjected to boat noise.

Another response to environmental and physiological stress is the production of stress or heat-shock proteins (HSPs). In crustaceans, the expression of Hsp70 serves as a good bioindicator of stressful conditions, including pesticide exposure and heat stress (Snyder and Mulder, 2001; Liberge and Barthélémy, 2007;). Only a few studies have examined the effects of noise on Hsp expression (Hoekstra et al., 1998; Wu et al., 2001; Celi et al., 2013). Recently, increased Hsp70 expression levels were detected in Chromis chromis after exposure to sounds similar to those resulting from human activities (Celi et al., unpublished). Moreover, in the present 
study, we show for the first time that acoustic stimuli induce Hsp70 overexpression in P. elephas haemocytes.

\section{Conclusion}

Exposure to acoustic pollution altered certain locomotor behavioural patterns and components of the haemato-immunological system of $P$. elephas.

In this study, the variability of the cellular and biochemical parameters in $P$. elephas was shown to be related to behavioural changes. Investigations of the behavioural and biochemical parameters analysed may contribute to understanding the basic biology and conservation of this species, in that the different patterns of metabolic response can manifest themselves in physiological, ecological, and behavioural changes. Moreover, quantification of these different stress responses may serve as early indicators of the degradation of environmental health.

In most natural marine environments, the soundscape has been permanently altered as a result of anthropogenic activities, characterised by impulsive and continuous noises, and the impact on marine organisms should be investigated over short-, mediumand long-term exposure periods. However, to increase the available information about the effects of noise on the behavioural and physiological responses, further studies should also be performed in an open natural environment where the acoustical field is not influenced by walls as it is in the small tanks.

\section{References}

Amoser, S., Ladich, F., 2003. Diversity in noise-induced temporary hearing loss in otophysine fishes. J. Acoust. Soc. Am. 113, 2170-2179.

Andriguetto-Filho, J.M., Ostrensky, A., Pie, M.R., Silva, U.A., Boeger, W.A., 2005 Evaluating the impact of seismic prospecting on artisanalshrimp fisheries. Cont. Shelf Res. 25, 1720-1727.

Arcos, G.F. Ibarra, A.M., Vazquez-Boucard, C., Palacios, E., Racotta, I.S., 2003. Haemolymph metabolic variables in relation to eyestalk ablation and gonad development of Pacific white shrimp Litopenaeus vannamei Boone. Aquac. Res. 34, 749-755.

Au, W.W., Floyd, R.W., Penner, R.H., Murchison, A.E., 1974. Measurement of echolocation signals of the Atlantic bottlenose dolphin, Tursiops truncatus Montagu, in open waters. J. Acoust. Soc. Am. 56, 1280-1290.

Bauchau, A.G., 1980. Crustaceans. In: Ratcliffe, N.A., Rowley, A.F. (Eds.), Invertebrate Blood Cells. Academic Press, New York, pp. 385-420.

Blonder, B.I., Hunt, J.H., Forcucci, D., Lyons, W.G., 1992. Effects of recreational and commercial fishing on spiny lobster abundance at Looe Key National Marine Sanctuary. Proc. Gulf Caribbean Fish. Inst. 41, 487-491.

Boisclair, D., Pascal, S., 1993. Testing assumptions of fish bioenergetics models by direct estimation of growth, consumption, and activity rates. Trans. Amer. Fish. Soc. $122,784-796$.

Bouwma, P.E., Herrnkind, W.F., 2009. Sound production in Caribbean spiny lobster Panulirusargus and its role in escape during predatory attack by Octopus briareus. New Zeal J. Mar. Fresh. 43, 3-13.

Bridges, C.M., 1997. Tadpole swimming performance and activity affected by acute exposure to sublethal levels of carbaryl. Environ. Toxicol. Chem. 16, 1935-1939.

Briones, P., Candela, J., Lozano, E., 2008. Postlarval settlement of the spiny lobster Panulirus argus along the Caribbean coast of Mexico: patterns, influence of physical factors, and possible sources of origin. Limnol. Oceanogr. 53, 970-985.

Brock, V.E., Riffenburgh, R.H., 1960. Fish schooling: a possible factor in reducing predation. J. Cons. 25, 307-317.

Buckup, L., Dutra, B.K., Ribarcki, F.P., Fernandes, F.A., Noro, C.K., Oliveira, G.T., Vinagre, A.S., 2008. Seasonal variations in the biochemical composition of the crayfish Parastacus defossus (Crustacea, Decapoda) in its natural environment. Comp. Biochem. Physiol. A: Mol. Integr. Physiol. 149, 59-67.

Buscaino, G., Filiciotto, F., Buffa, G., Bellante, A., Di Stefano, V., Assenza, A., Fazio, F., Caola, G., Mazzola, S., 2010. Impact of an acoustic stimulus on the motility and blood parameters in European sea bass (Dicentrarchus labrax L.) and gilthead sea bream (Sparus aurata L.). Mar. Environ. Res. 69, 136-142.

Buscaino, G., Filiciotto, F., Gristina, M., Bellante, A., Buffa, G., Di Stefan, V., Maccarrone, V., Tranchida, G., Buscaino, C., Mazzola, S., 2011a. Acoustic behaviour of the European spiny lobster. Palinurus elephas. Mar. Ecol. Prog. $441,177-184$.

Buscaino, G., Filiciotto, F., Gristina, M., Buffa, G., Bellante, A., Maccarrone, V., Patti, B., Mazzola, S., 2011b. Defensive strategies of European spiny lobster Palinurus elephas during predator attack. Mar. Ecol. Prog. 423, 143-154.

Celi, M., Filiciotto, F., Parrinello, D., Buscaino, G., Damiano, M.A., Cuttitta, A., D’Angelo, S., Mazzola, S., Vazzana, M., 2013. Physiological and agonistic behavioural response of Procambarus clarkii to an acoustic stimulus. J. Exp. Biol. 216, 709-718.

Chang, E.S., 2005. Stressed-out lobsters: crustacean hyperglycemic hormone and stress proteins. Integr. Comp. Biol. 45, 43-50.

Childress, M.J., Herrnkind, W.F., 1997. Den sharing by juvenile Caribbean spiny lobsters (Panulirus argus) in nursery habitat: cooperation or coincidence? Mar. Freshwater. Res. 48, 751-758.

Childress, M.J., Herrnkind, W.F., 2001. The guide effect influence on the gregariousness of juvenile Caribbean spiny lobsters. Anim. Behav. 62, 465-472.

Christian, J., 2003. White's Cove Quarry Blasting: Potential Impacts on American Lobster. LGL Limited, St. John's, NL.

Codarin, A. Wysocki, L.E., Ladich, F., Picciulin, M., 2009. Effects of ambient and boat noise on hearing and communication in three fish species living in a marine protected area (Miramare, Italy). Mar. Pollut. Bull. 58, 1880-1887.

Da Silva-Castiglioni, D., Dutra, B.K., Oliveira, G.T., Buckup, G.B., 2007. Seasonal variations in the intermediate metabolism of Parastacus varicosus (Crustacea, Decapoda, Parastacidae). Comp. Biochem. Phys. A 148, 204-213.

Davis, G.E., Dodrill, J.W., 1989. recreational fishery and population dynamics of spiny lobsters, Panulirus argus, in Florida Bay, Everglades National Park, 19771980. B. Mar Sci. 44, 78-88.

Depledge, M.H., Bjerregaard, P., 1989. Haemolymph protein composition and copper levels in decapod crustaceans. Helgoland Mar. Res. 43, 207-223.

Durand, F., Devillers, N., Lallier, F.H., Regnault, M., 2000. Nitrogen excretion and change in blood components during emersion of the subtidal spider crab Maia squinado (L.). Comp. Biochem. Phys. A 127, 259-271.

Endler, J.A., Interactions between predators and prey. 1991. In: Krebs, J.R.N., Davies, B. (Eds.), Behavioural ecology: an evolutionary approach. 3, pp. 169-196.

Engås, A., Løkkeborg, S., Ona, E., Soldal, A.V., 1996. Soldal effects of seismic shooting on local abundance and catch rates of cod (Gadus morhua) and haddock (Melanogrammus aeglefinus). Can. J. Fish. Aqua. Sci. 53, 2238-2249.

Filiciotto, F., Giacalone, V.M., Fazio, F., Buffa, G., Piccione, G., Maccarrone, V., Di Stefano, V., Mazzola, S., Buscaino, G., 2013. Effect of acoustic environment on gilthead sea bream (Sparus aurata): sea and onshore aquaculture background noise. Aquaculture 414-415, 36-45.

Follesa, M.A., Cuccu, D., Cannas, R., Sabatini, A., Deiana, A.M., Cau, A., 2009. Movement patterns of the spiny lobster Palinurus elephas (Fabricius 1787) from a centre western mediterranean protected area. Sci. Mar. 73, 499-506.

Golet, W.J., Scopel, D.A., Cooper, A.B., Watson III, W.H., 2006. Daily patterns of locomotion expressed by American lobsters (Homarus americanus) in their natural habitat. J. Crustacean Biol. 26, 610-620.

Goni, R., Latrouite, D., 2005. Review of the biology, ecology and fisheries of Palinurus spp. species of European waters: Palinurus elephas (Fabricius, 1787) and Palinurus mauritanicus (Gruvel, 1911). Cah. Biol. Mar. 46, 127-142.

Groeneveld, J.C., Goñi, R., Latrouite, D., 2006. Palinurus species. In: Phillips, B.F. (Ed.), Lobsters: Biology, Management, Aquaculture and Fisheriesm. Blackwell Scientific Publications, Oxford, Chapter 12.

Hagerman, L., 1983. Haemocyanin concentration of juvenile lobsters (Homarus gammarus) in relation to moulting cycle and feeding conditions. Mar. Biol. 77, $11-17$.

Henry, M.G., Gary, J.A., 1986. Behavioral changes in social groups of bluegills exposed to copper. T. Am. Fish. Soc. 115, 590-595.

Herrnkind, W.F., 1983. Movement patterns and orientation. In: Vernberg, F.J., Vernberg, W.B. (Eds.), The biology of Crustacea, vol. 7. Behavior and Ecology, pp. 41-105.

Herrnkind, W.F., Childress, M.J., Lavalli, K.L., 2001. Cooperative defiance and other benefits among exposed spiny lobsters: inferences from group size and behavior. Mar. Freshwater Res. 52, 1113-1124.

Hildebrand, J.A., 2009. Anthropogenic and natural sources of ambient noise in the ocean. Mar. Ecol. Prog. Ser. 395, 5-20.

Hoekstra, K.A., Iwama, G.K., Nichols, C.R., Godin, D.V., Cheng, K.M., 1998. Increased heat shock protein expression after stress in Japanese quail. Stress 2, 265-272.

Hunter, E., 1999. Biology of the European spiny lobster Palinurus elephas (Fabricius, 1787) (Decapoda: Palinuridea). Crustaceana 72, 545-565.

Johansson, M., Keyser, W., Sritunyalucksana, P.K., Soderhall, K., 2000. Crustacean haemocytes and haematopoiesis. Aquaculture 191, 45-52.

Jussila, J., Jago, J., Tsvetnenko, E., Dunstan, B., Evans, H., 1997. Total and differential hemocyte counts in western rock lobster (Panulirus cygnus) under post-harvest stress. Mar. Freshwater Res. 48, 863-867.

Kanciruk, P., 1980. Ecology of juvenile and adult Palinuridae (Spiny lobsters). In: Cobb, J.S., Phillips, B.F. (Eds.), The biology and management of lobsters, vol. II. Academic, Nueva York, pp. 59-96.

Laemmli, U.K., 1970. Cleavage of structural proteins during the assembly of the head of bacteriophage T4. Nature 227, 680-685.

Lavalli, K.L., Herrnkind, W.F., 2009. Collective defense by spiny lobster (Panulirus argus) against triggerfish (Balistes capriscus): effects of number of attackers and defenders. N. Z. J. Mar. Freshw. Res. 43, 15-28.

Lawton, P., Lavalli, K.L., 1995. Postlarval, juvenile, adolescent, and adult ecology. In: Factor, J.R. (Ed.), Biology of the lobster Homarus americanus. Academic Press, San Diego, pp. 47-88.

Le Moullac, G., Soyez, C., Saulnier, D., Ansquer, D., Avarre, J.C., Levy, P., 1998. Effect of hypoxic stress on the immune response and the resistance to vibriosis of the shrimp Penaeus stylirostris. Fish Shellfish Immun. 8, 621-629.

Li, C., Shields, J.D., 2007. Primary culture of hemocytes from the Caribbean spiny lobster, Panulirus argus, and their susceptibility to Panulirus argus Virus 1 (PaV1). J. Invertebr. Pathol. 94, 48-55. 
Liberge, M., Barthélémy, R.M., 2007. Localization of metallothionein, heat shock protein (Hsp70), and superoxide dismutase expression in Hemidiaptomusroubaui (Copepoda, Crustacea) exposed to cadmium and heat stress. Can. J. Zool. 85, 362-371.

Lin, C.H., Chen, J.C., 2001. Hemolymph oxyhemocyanin and protein levels and acidbase balance in the tiger shrimp Penaeus monodon exposed to copper sulfate. J. World Aquacult. Soc. 32, 335-341.

Lorenzon, S., Edomi, P., Giulianini, P.G., Mettulio, R., Ferrero, E.A., 2004. Variation of crustacean hyperglycemic hormone $(\mathrm{CHH})$ level in the eyestalk and haemolymph of the shrimp Palaemon elegans following stress. J. Exp. Biol. 207, 4205-4213.

Lorenzon, S., Martinis, M., Ferrero, E.A., 2011. Ecological relevance of hemolymph total protein concentration in seven unrelated crustacean species from different habitats measured predictively by a density-salinity refractometer. J. Mar. Biol. 2011, 1-7.

Magurran, A.E., 1990. The adaptive significance of schooling as an anti-predator defense in fish. Ann. Zool. Fennici. 27, 51-66.

Mahmood, A., Yousaf, M., 1985. Effect of some insecticides on the haemocytes of Gryllus bimaculatus de Geer. Pak. J. Zool. 17, 71-84.

McIntyre, A.D., 1995. Human impact on the oceans: the 1990s and beyond. Mar. Pollut. Bull. 31, 147-151.

Mercer, J.P., 1973. Studies on the spiny lobsters (Crustacea: Decapoda: Palinuridae) of the West Coast of Ireland with particular reference to Palinurus elephas, Fabricius 1787. Unpublished PhD thesis, University College Galway, Ireland.

Mercier, L., Palacios, E., Campa-Córdova, Á.I., Tovar-Ramírez, D., Hernández-Herrera, R., Racotta, I.S., 2006. Metabolic and immune responses in Pacific whiteleg shrimp Litopenaeus vannamei exposed to a repeated handling stress. Aquaculture 258, 633-640.

Milinski, M., Parker, G.A., 1991. Competition for resources. In: Krebs, J.R., Davies, N.B. (Eds.), Behavioural Ecology. An Evolutionary Approach. Blackwell Scientific Publications, Oxford, pp. 137-168.

Myrberg Jr., A.A., 1990. The effects of man-made noise on the behavior of marine animals. Environ. Int. 16, 575-586.

National Research Council, 2003. Ocean noise and marine mammals. Effects of Noise on Marine Mammals. National Academy Press, Washington, DC.

National Research Council, 2005. Marine Mammal Populations and Ocean Noise Determining When Noise Causes Biologically Significant Effects. National Academy Press, Washington, DC.

Newland, P.L., Chapman, C.J., 1989. The swimming and orientation behaviour of the Norway lobster, Nephrops norvegicus (L.) in relation to trawling. Fish. Res. 8, 6380.

O'Brien, D.P., 1988. Surface schooling behaviour of the coastal krill Nyctiphanes australis (Crustacea: Euphausiacea) off Tasmania. Aust. Mar. Ecol. Prog. Ser. 42, 219-233.

Ocampo, L., Patino, D., Ramırez, C., 2003. Effect of temperature on hemolymph lactate and glucose concentrations in spiny lobster Panulirus interruptus during progressive hypoxia. J. Exp. Mar. Biol. Ecol. 296, 71-77.

Oliveira, G.T., Fernandes, F.A., Bueno, A.A.P., Bond-Buckup, G., 2007. Seasonal variations in the intermediate metabolism of Aegla platensis (Crustacea, Aeglidae). Comp. Biochem. Physiol. Part. A. 147, 600-606.

Oliver, M.D., MacDiarmid, A.B., 2001. Blood refractive index and ratio of weight to carapace length as indices of nutritional condition in juvenile rock lobsters (Jasus edwardsii) Mar. Freshwater Res. 52, 1395-1400.

Ozbay, G., Riley, J.G., 2002. An analysis of refractometry as a method of determining blood total protein concentration in the American lobster Homarus americanus (Milne Edwards). Aquaculture Res. 33, 557-562.

Palacios, E.A., Ibarra, M., Racotta, I.S., 2000. Tissue biochemical composition in relation to multiple spawning in wild and pond-reared Penaeus vannamei broodstock. Aquaculture 185, 353-371.

Parsons, D.M., Eggleston, D.B., 2005. Indirect effects of recreational fishing on behavior of the spiny lobster Panulirus argus. Mar. Ecol. Prog. Ser. 303, 235-244.

Pascual, C., Sánchez, A., Zenteno, E., Cuzon, G., Gabriela, G., Brito, R., Gelabert, R., Hidalgo, E., Rosas, C., 2006. Biochemical, physiological, and immunological changes during starvation in juveniles of Litopenaeus vannamei. Aquaculture 251, 416-429.

Patek, S.N., Baio, J.E., 2007. The acoustic mechanics of stick-slip friction in the California spiny lobster (Panulirus interruptus). J. Exp. Biol. 210, 3538-3546.

Patek, S.N., Oakley, T.H., 2003. Comparative tests of evolutionary trade-offs in a palinurid lobster acoustic system. Evolution 57, 2082-2100.

Patek, S.N., 2001. Spiny lobsters stick and slip to make sound. Nature 411, 153-154.

Patek, S.N., 2002. Squeaking with a sliding joint: mechanics and motor control of sound production in palinurid lobsters. J. Exp. Biol. 205, 2375-2385.

Payne, J.F., Andrews, C.A., Fancey, L.L., Cook, A.L., Christian, J.R., 2007. Pilot study on the effect of seismic air gun noise on lobster (Homarus americanus). Can. Tech. Rep. Fish. Aquat. Sci. 171, 34.

Perazzolo, L.M., Gargioni, R., Ogliari, P., Barracco, M.A.A., 2002. Evaluation of some hemato-immunological parameters in the shrimp Farfantepenaeus paulensis submitted to environmental and physiological stress. Aquaculture 214, 19-33.
Popper, A.N., Fewtrell, J., Smith, M.E., McCauley, R.D., 2004. Anthropogenic sound: effects on the behavior and physiology of fishes. Mar. Technol. Soc. J. 37, 35-40.

Popper, A.N., Smith, M.E., Cott, P.A., Hanna, B.W., MacGillivray, A.O., Austin, M.E., Mann, D.A., 2005. Effects of exposure to seismic air gun use on hearing of three fish species. J. Acoust. Soc. Am. 117, 3958-3971.

Reed, J.M., Dobson, A.P., 1993. Behavioral constraints and conservation biology: conspecific attraction and recruitment. Trends Ecol. Evol. 8, 253-256.

Romano, T.A., Keogh, M.J., Kelly, C., Feng, P., Berk, L., Schlundt, C.E., Carder, D.A. Finneran, J.J., 2004. Anthropogenic sound and marine mammal health: measures of the nervous and immune systems before and after intense sound exposure. Can. J. Fish. Aquat. Sci. 61, 1124-1134.

Ross, D., 2005. Ship sources of ambient noise. IEEE J. Ocean. Eng. 30, 257-261.

Saglio, P., Trijasse, S., 1998. Behavioral responses to atrazine and diuron in goldfish. Arch. Environ. Con. Tox. 35, 484-491.

Sánchez, A., Pascual, C., Sánchez, A., Vargas-Albores, F., Le Moullac, G., Rosas, C., 2001. Hemolymph metabolic variables and immune response in Litopenaeus setiferus adult males: the effect of acclimation. Aquaculture 198, 13-28.

Sandström, A., Eriksson, B.K., Karås, P., Isæus, M., Schreiber, H., 2005. Boating and navigation activities influence the recruitment of fish in a Baltic Sea archipelago area. Ambio 34, 125-130.

Santulli, A., Modica, A., Messina, C., Ceffa, L., Curatolo, A., Rivas, G., Fabi, G., D’Amelio V., 1999. Biochemical responses of European sea bass (Dicentrarchus labrax L.) to the stress induced by offshore experimental seismic prospecting in the mediterranean sea. Mar. Pollut. Bull. 38, 1105-1114.

Sarà, G., Dean, J.M., D’Amato, D., Buscaino, G., Oliveri, A., Genovese, S., Ferro, S., Buffa, G., Lo Martire, M., Mazzola, S., 2007. Effect of shipping traffic on behaviour of bluefin tuna Thunnus thynnus. Mar. Ecol. Prog. Ser. 331, 243-253.

Scholik, A.R., Yan, H.Y., 2001. Effects of underwater noise on auditory sensitivity of a cyprinid fish. Hearing Res. 152, 17-24.

Shabani, S., Kamio, M., Derby, C.D., 2008. Spiny lobsters detect conspecific bloodborne alarm cues exclusively through olfactory sensilla. J. Exp. Biol. 211, 2600 2608.

Shafir, S., Tom, M., Ovadia, M., Lubzens, E., 1992. Protein, vitellogenin and vitellin levels in the hemolymph and ovaries during ovarian development in Penaeus semisulcatus (de Haan). Biol. Bull. 183, 394-400.

Smith, M.E., Kane, A.S., Popper, A.N., 2004. Noise-induced stress response and hearing loss in goldfish (Carassius auratus). J. Exp. Biol. 207, 427-435.

Snyder, M.J., Mulder, E.P., 2001. Environmental endocrine disruption in decapod crustacean larvae: hormone titers, cytochrome P450, and stress protein responses to heptachlor exposure. Aquat. Toxicol. 55, 177-190.

Spanier, E., Tom, M., Pisant, S., Almog, G., 1988. Seasonality and shelter selection by the slipper lobster Scyllarides latus in the southeastern Mediterranean. Mar. Ecol. Prog. Ser. 42, 247-255.

Speed, S.R., Baldwin, J., Wong, R.J., Wells, R.M.G., 2001. Metabolic characteristics of muscles in the spiny lobster, Jasus edwardsii, and responses to emersion during simulated live transport. Comp. Biochem. Physiol. 128, 435-444.

Staaterman, E.R., Claverie, T., Patek, S.N., 2010. Disentangling defense: the function of spiny lobster sounds. Behaviour 147, 235-258.

Stamps, J.A., 1994. Territorial behavior: testing the assumptions. Adv. Stud. Behav. 23, 173-232.

Stentiford, G.D., Chang, E.S., Chang, S.A., Neil, D.M., 2001. Carbohydrate dynamics and the crustacean hyperglycemic hormone $(\mathrm{CHH})$ : effects of parasitic infection in Norway lobsters (Nephrops norvegicus). Gen. Comp. Endocrinol. 121, $13-22$.

Stephens, P.A., Sutherland, W.J., 1999. Consequences of the Allee effect for behaviour, ecology and conservation. Trends Ecol. Evol. 14, 401-405.

Sun, Y., Song, Y., Zhao, J., Chen, J., Yuan, Y., Jiang, S., Zhang, D., 2001. Effect of drilling noise and vibration on growth of carp (Cyprinus carpio) by cut-fin marking. Mar. Fish. Res. 22, 62-68.

Thomas, J.A., Kastelein, R.A., Awbrey, F.T., 1990. Behavior and blood catecholamines of captive belugas during playbacks of noise from an oil drilling platform. Zoo. Biol. 9, 393-402.

Vehrencamp, S.L., 1983. Optimal degree of skew in cooperative societies. Am. Zool. 23, 327-335.

Vinagre, A.S., Amaral, A.P.N., Ribarcki, F.P., Silveira, E.F., Périco, E., 2007. Seasonal variation of energy metabolism in ghost crab Ocypode quadrata at Siriú Beach (Brazil). Comp. Biochem. Physiol. 146, 514-519.

Wainwright, P.C., Friel, J.P., 2000. Effects of prey type on motor pattern variance in tetraodontiform fishes. J. Exp. Zool. 286, 563-571.

Wale, M.A., Simpson, S.D., Radford, A.N., 2013. Noise negatively affects foraging and antipredator behaviour in shore crabs. Anim. Behav. 86, 111-118.

Wysocki, L.E., Dittami, J.P., Ladich, F., 2006. Ship noise and cortisol secretion in European freshwater fishes. Biol. Conserv. 128, 501-508.

Wu, T., Ma, J., Chen, S., Sun, Y., Xiao, C., Gao, Y., Wang, R., Poudrier, J., Dargis, M., Currie, R.W., 2001. Association of plasma antibodies against the inducible Hsp70 with hypertension and harsh working conditions. Cell Stress Chaperon. 6, 394-401. 